\title{
MODEL PERADILAN RESTORATIF DALAM SISTEM PERADILAN ANAK (Kajian tentang Praktik Mediasi Pelaku dan Korban dalam Proses Peradilan Anak di Wilayah Hukum Balai Pemasyarakatan Purwokerto)
}

\author{
Oleh: \\ Angkasa, Saryono Hanadi, dan Muhammad Budi Setyadi \\ Fakultas Hukum Universitas Jenderal Soedirman \\ drangkasa_64@yahoo.com
}

\begin{abstract}
Legal fundament of implementation of restorative justice in the phase investigation of juvenile justice system in Indonesia stated in article 5 sentence (1) Law No. 8 Year 1981 concerning KUHAP; article 42 Law No. 3 Year 1997 concerning juvenile court, article 16 sentence (1) letter (l), sentence (2) and article 18 Law No. 2 Year 2002 concerning Police Department of Republic of Indonesia, Confidential Telegram of Kabareskrim No. Pol. TR/359/DIT,I/VI/2008. Mediation Perpetrator and Victim in the course of Jurisdiction of Child in jurisdiction territory of prison in Purwokerto, in the form of peace among victim and perpetrator of this child, is conducted in inspection phase, is in prosecution phase and inspection of justice have never been conducted by mediation. Implementation of Mediation in case of child in Jurisdiction territory of Bapas Purwokerto, not yet earned a Restorative Justice Model. This Matter is based on fact that goals of this mediation practice tend to only aim to decontrol continuation.
\end{abstract}

Kata kunci: Juvenile Justice System; Restorative Justice Model; Mediation; prison.

\section{A. Latar Belakang}

Data pada statistik kriminal kepolisian, kejahatan yang dilakukan oleh anak tiap tahun semakin meningkat, terutana kejahatan terhadap harta benda, penganiayaan dan kejahatan kesusilaan. Saat ini Lembaga Pemasyarakatan Anak di Indonesia kewalahan karena isinya melebihi kapasitas dalam Pembinaan anak nakal. Kondisi demikian tentunya sangat tidak mendukung dan menghambat pelaksanaan pembinaan terhadap anak nakal.

Berdasarkan penelitian, kebijakan penjatuhan pidana (khususnya pidana penjara) terhadap anak nakal (delinkuen) menunjukkan adanya kecenderungan bersifat merugikan perkembangan jiwa anak dimasa mendatang. Kecenderungan bersifat merugikan ini akibat dari efek penjatuhan pidana yang berupa stigma. ${ }^{1}$ Kecenderungan sifat merugikan ini karena model peradilan pidana terhadap anak menggunakan model peradilan retributif, dan tidak menggunakan model peradilan restoratif.

Paulus Hadisuprapto, 1997, Juvenile Delinquency Pemahaman dan Penannggulangannya, Bandung: PT. Citra Aditya Bakti.
Wacana peradilan restoratif tampak masih menjadi masalah karena masih terdapat ketidakjelasan tentang dasar hukum yang dijadikan acuan sebagai dasar pijakan pembenaran implementasi peradilan restoratif. Namun demikian berdasarkan hasil penelitian, dalam praktik terdapat indikasi praktek peradilan restoratif dalam proses peradilan anak, misalnya:

a. dikembalikan kepada orang tuanya;

b. diselesaikan secara kekeluargaan/perdamaian atau non-litigasi. ${ }^{2}$

Dengan kondisi demikian maka hal ini menandakan bahwa telah terdapat ciri-ciri peradilan restoratif dalam proses pemeriksaan perkara anak di Balai Pemasyarakatan Purwokerto. Namun demikian perlu ditelaah lebih lanjut, apakah tindakan-tindakan yang dilakukan oleh Bapas dan Kepolisian dalam penyelesaian non-litigasi, mediasi, perdamaian

Setya Wahyudi, 2007, Penelitian dan Pengembangan Diversi dalam Sistem Peradilan Anak dalam Sistem Peradilan Pidana Anak di Indonesia, Hasil Penelitian, Fakultas Hukum Unsoed, Purwokerto. 
tersebut dapat dikategorikan implementasi peradilan restoratif dalam sistem peradilan anak.

\section{B. Perumusan Masalah}

1. Bagaimanakah dasar hukum penerapan peradilan restoratif dalam sistem peradilan anak di Indonesia?

2. Bagaimanakah praktik mediasi dan konsiliasi antara korban dan pelaku dalam proses peradilan pidana anak di lokasi penelitian?

3. Apakah praktik mediasi dan konsiliasi antara korban, pelaku dalam proses peradilan pidana anak di lokasi penelitian, merupakan implementasi model peradilan restoratif dalam sistem peradilan anak?

\section{Metode Penelitian}

\section{Metode Pendekatan}

Penelitian ini menggunakan dua metode pendekatan, yaitu pendekatan yuridis normatif dan yuridis sosiologis. Pendekatan yuridis normatif digunakan untuk mengetahui secara normatif tentang perlindungan anak dalam sistem peradilan pidana anak. Di dalam pendekatan yuridis normatif didahului dengan inventarisasi hukum positif yang mengatur perlindungan anak dalam sistem peradilan pidana, selanjutnya dikaji tentang asas-asas hukum, penemuan hukum in concreto dan taraf sinkronisasi vertikal dan horisontal. Sedangkan pendekatan yuridis sosiologis digunakan untuk mengetahui pelaksanaan perlindungan anak dalam praktek sistem peradilan pidana, di mana terdapat aspek-aspek sosial yang mempengaruhinya dalam bekerjanya hukum di masyarakat (law in action).

\section{Data}

Data penelitian ini terdiri atas data primer dan data sekunder. Data primer adalah data yang bersumber dari pendapat langsung para responden, yang dalam hal ini meliputi:

1) Polisi, Jaksa, Hakim dan Penasihat Hukum;

2) Pembina Balai Pemasyarakatan;

3) Anak Pelaku tindak pidana dan Orang tua/ keluarganya;

4) Korban dan keluarga korban;
5) Tokoh masyarakat dan LSM;

6) Pakar hukum pidana anak.

Data sekunder berupa data berupa dokumen-dokumen terdiri: peraturan perundangundangan yaitu: UU No. 8 Tahun 1981 tentang KUHAP; UU No. 3 Tahun 1997 tentang Pengadilan Anak; UU No. 2 tahun 2002 tentang Kepolisian Negara RI; UU No. 23 Tahun 2002 tentang Perlindungan Anak; Kepres No. 36 Tahun 1990 tentang Konvensi Hak-Hak Anak; Surat Telegram Rahasia Kabareskrim Polri No. Pol. TR/359/DIT.I/VI/2008 dan Surat Telegram Rahasia dari Kapolda Jateng No. Pol. STR/215/ III/2009; literatur; jurnal; hasil penelitian; serta dokumen/ arsip di Balai Pemasyarakatan Purwokerto dan Polres.

3. Lokasi Penelitian Lokasi penelitian :

1) Polres Banyumas; Purwokerto; Cilacap; Purbalingga; Banjar Negara; dan Kebumen.

2) Kejaksaan Banyumas; Purwokerto; Cilacap; Purbalingga; Banjar Negara; dan Kebumen.

3) Pengadilan Negeri Banyumas; Purwokerto; Cilacap; Purbalingga; Banjar Negara; dan Kebumen.

4) Balai Pemasyarakatan Purwokerto.

\section{Metode Pengumpulan Data}

Metode pengumpulan data dalam penelitian ini menggunakan lintas metode (triangulasi metoda), yaitu studi pustaka, wawancara, dan observasi sesuai dengan jenisjenis sumber data yang diperlukan. Studi pustaka dilakukan terhadap data sekunder yang diperoleh dengan mempelajari peraturan perundang-undangan, literatur, hasil penelitian serta dokumen-dokumen resmi yang berkaitan dengan obyek penelitian. Metode pengumpulan data primer dengan metode wawancara bebas terpimpin secara mendalam, dengan responden yang diambil secara porposive/non random sampling, sehingga dalam penelitian ini jumlah responden sebagai berikut.

1) Polisi 12 orang (tiap-tiap Polres 2 orang);

2) Jaksa penuntut umum 6 orang;

3) Hakim 6 orang

4) Penasehat hukum 6 orang

5) Pembina Bapas Purwokerto 2 orang; 
188 Jurnal Dinamika Hukum

Vol. 9 No. 3 September 2009

6) Orang tua/keluarga anak nakal 6 orang

7) Tokoh masyarakat/LSM 6 orang;

8) Pakar hukum pidana anak 2 orang.

Metode observasi dilakukan sebagai pengamatan dan pencatatan secara sistematis terhadap gejala-gejala sosial yang diselidiki. Observasi ini dilakukan untuk mendapatkan data yang tidak bisa didapatkan dengan interview.

\section{Instrumen Panelitian}

Instrumen utama dalam penelitian ini adalah peneliti sendiri. Dalam penelitian ini, tim peneliti sendiri terjun langsung ke site penelitian. Instrumen lain yang digunakan adalah pedoman wawancara dan blanko dokumentasi, tape rekorder serta tustel untuk merekam data sekunder.

\section{Metode Penyusunan Data}

Data sekunder yang didapat dari studi dokumen, dan data primer yang didapat dari wawancara dan data hasil dai observasi dikumpulkan, untuk selanjutnya disusun secara sistematis. Penyusunan hasil penelitian yang telah terkumpul, disajikan secara narasi dan tabel-tabel secara sistematis sesuai dengan urutan permasalahan yang dimunculkan.

\section{Metode Analisis Data}

Metode analisis data yang digunakan adalah kuantitatif dan kualitatif. Analisis kuantitatif dilakukan terhadap data yang bersifat kuantitatif, untuk menyimpulkan adanya kecenderungan-kecenderungan berdasarkan frekuensi-frekuensi dalam tabel. Analisis kualitatif dilakukan terhadap data yang bersifat kualitatif, mendasarkan pada norma-norma yang berlaku secara nasional maupun internasional dan berdasarkan teori model restorative justice dalam sistem peradilan pidana anak; teori mediasi sebagai penyelesaian konflik; dan teori diskresi dalam penegakan hukum pidana.

\section{Pembahasan}

\section{Peradilan Restoratif dalam Sistem Peradilan Pidana Anak}

Peradilan restoratif untuk menghasilkan keadilan restoratif, yaitu suatu proses dimana semua pihak yang terlibat dalam suatu tindak pidana tertentu bersama-sama memecahkan masalah bagaimana menangani akibatnya di masa yang akan datang. Tindak pidana yang dilakukan anak adalah suatu pelanggaran terhadap manusia dan relasi antar manusia. Tindak pidana menciptakan suatu kewajiban untuk membuat segala sesuatunya menjadi lebih baik dengan melibatkan korban, pelaku dan masyarakat dalam mencari solusi untuk memperbaiki, rekonsiliasi dan menenteramkan hati. $^{3}$

Prinsip-prinsip peradilan restoratif berbeda dengan model peradilan konvensional, yaitu:

a. Membuat pelanggar bertanggung jawab untuk memperbaiki kerugian yang ditimbulkan untuk memperbaiki kerugian yang ditimbulkan oleh kesalahannya;

b. Memberikan kesempatan kepada pelanggar untuk membuktikan kapasitas dan kualitasnya di samping mengatasi rasa bersalahnya secara konstruktif;

c. Melibatkan para korban, orang tua, keluarga, sekolah dan teman sebaya;

d. Menciptakan forum untuk bekerja sama dalam menyelesaikan masalah;

e. Menetapkan hubungan langsung dan nyata antara kesalahan dengan reaksi sosial yang formal.

Pelaksanaan peradilan restoratif dapat dilakukan melalui kegiatan-kegitan seperti: Mediasi korban dengan pelaku/pelanggar; Musyawarah kelompok keluarga; Pelayanan di masyarakat yang bersifat pemulihan baik bagik korban maupun pelaku. Tujuan penyelenggaraan sistem peradilan pidana, tergantung pada model sistem tersebut, yaitu model peradilan retributif atau model peradilan restoratif. Sebagai perbandingan antara model peradilan tersebut dapat dilihat dalam bagan sebagai berikut. ${ }^{4}$

Apong Herlina, dkk., 2004, Perlindungan Terhadap Anak
Yang Berhadapan dengan Hukum Manual Pelatihan

Apong Herlina, dkk., 2004, Perlindungan Terhadap Anak
Yang Berhadapan dengan Hukum Manual Pelatihan Untuk POLISI, Jakarta: Polri dan Unicef. $4 \quad$ Ibid 
Tabel 1

Perbandingan antara Model Peradilan Retributif dan Restoratif

\begin{tabular}{|l|l|l|}
\hline No. & \multicolumn{1}{|c|}{$\begin{array}{c}\text { Model peradilan } \\
\text { Retributif }\end{array}$} & \multicolumn{1}{|c|}{$\begin{array}{c}\text { Model peradilan } \\
\text { Restoratif }\end{array}$} \\
\hline 1 & $\begin{array}{l}\text { Fokus pada penjatuhan } \\
\text { kesalahan, menimbulkan } \\
\text { rasa bersalah, pada pe- } \\
\text { rilaku masa lalu }\end{array}$ & $\begin{array}{l}\text { Fokus pada pemecahan } \\
\text { masalah dan memper- } \\
\text { baiki kerugian }\end{array}$ \\
\hline 2 & Korban diabaikan & $\begin{array}{l}\text { Hak dan kebutuhan } \\
\text { Korban diperhatikan }\end{array}$ \\
\hline 3 & Pelaku pasif & $\begin{array}{l}\text { Pelaku didorong untuk } \\
\text { bertanggung jawab }\end{array}$ \\
\hline 4 & $\begin{array}{l}\text { Pertanggungjawaban } \\
\text { pelaku adalah hukuman }\end{array}$ & $\begin{array}{l}\text { Pertanggungjawaban } \\
\text { pelaku adalah menun- } \\
\text { jukkan empati dan me- } \\
\text { nolong untuk memper- } \\
\text { baiki kerugian }\end{array}$ \\
\hline 5 & $\begin{array}{l}\text { Stigma tidak terhapus- } \\
\text { kan }\end{array}$ & $\begin{array}{l}\text { Stigma dapat hilang } \\
\text { melalui tindakan yang } \\
\text { tepat }\end{array}$ \\
\hline 6 & $\begin{array}{l}\text { Tidak didukung untuk } \\
\text { menyesal dan dimaafkan }\end{array}$ & $\begin{array}{l}\text { Didukung agar menyesal } \\
\text { dan maaf sangat mung- } \\
\text { kin diberikan }\end{array}$ \\
\hline 7 & $\begin{array}{l}\text { Bergantung pada aparat } \\
\text { penegak hukum }\end{array}$ & $\begin{array}{l}\text { Bergantung pada keter- } \\
\text { libatan langsung orang- } \\
\text { orang yang terpengaruh } \\
\text { oleh kejadian. }\end{array}$ \\
\hline
\end{tabular}

Berdasarkan bagan ini tampak bahwa pelaksanaan peradilan restoratif jika diterapkan dalam peradilan anak, maka agar dapat memujudkan:

a. Anak pelaku tindak pidana didorong untuk bertanggung jawab secara aktif;

b. Anak pelaku tindak pidana diharapkan untuk menunjukkan empati dan menolong memperbaiki kerugian dan tidak hanya difokuskan pada penghukuman;

c. Stigma (cap jahat) pada anak dapat terhapuskan;

d. Anak pelaku tindak pidana diharapkan untuk meminta maaf dan agar mempunyai rasa penyesalan;

e. Pelaksanaan peradilan anak restoratif memerlukan keterlibatan orang tua, masyarakat, korban, tokoh masyarakat serta penegak hukum;

f. Peradilan anak restoratif bertujuan untuk mencari solusi untuk memperbaiki, reskonsiliasi dan menenteramkan hati.

Muladi mengemukakan secara rinci ciriciri peradilan restoratif sebagai berikut :

a. Kejahatan dirumuskan sebagai pelanggaran seseorang terhadap orang lain dan dipandang sebagai konflik; b. Fokus perhatian pada pemecahan masalah pertanggungjawaban dan kewajiban untuk masa akan datang;

c. Sifat normatif dibangun atas dasar dialog dan negosiasi;

d. Restitusi sebagai sarana perbaikan para pihak, rekonsiliasi dan restorasi merupakan tujuan utama;

e. Keadilan dirumuskan sebagai hubungan antar hak, dinilai atas dasar hasil;

f. Fokus perhatian terarah pada perbaikan luka sosial akibat kejahatan;

g. Masyarakat merupakan fasilitator di dalam proses restoratif;

h. Peran korban dan pelaku diakui, baik dalam penentuan masalah maupun penyelesaian hak-hak dan kebutuhan korban. Pelaku didorong untuk bertanggung jawab;

i. Pertanggungjawaban pelaku dirumuskan sebagai dampak pemahaman atas perbuatannya dan diarahkan untuk ikut memutuskan yang terbaik;

j. Tindak pidana dipahami dalam konteks menyeluruh, moral, sosial dan ekonomis; dan

k. Stigma dapat dihapus melalui tindakan restoratif. $^{5}$

Menurut Gordon Bazemore, pokok-pokok pemikiran dalam paradigma peradilan anak Restoratif (restorative paradigm) sebagai berikut: ${ }^{6}$

a) Tujuan Penjatuhan Sanksi

Ada asumsi bahwa di dalam mencapai tujuan penjatuhan sanksi, maka diikut sertakan korban untuk berhak aktif terlibat dalam proses peradilan. Indikator pencapaian tujuan penjatuhan sanksi tercapai dengan dilihat pada apakah korban telah direstorasi, kepuasan korban, besarnya ganti rugi, kesadaran pelaku atas perbuatannya, jumlah kesepakatan perbaikan yang dibuat, kualitas pelayanan kerja dan keseluruhan proses yang terjadi.

\footnotetext{
5 Muladi, 2002, Kapita Selekta Sistem Peradilan Pidana, Semarang: Badan Penerbit Universitas Diponegoro.

6 Paulus Hadisuprapto, op.cit.
} 
190 Jurnal Dinamika Hukum

Vol. 9 No. 3 September 2009

Bentuk-bentuk sanksi yaitu restitusi, mediasi pelaku korban, pelayanan korban, restorasi masyarakat, pelayanan langsung pada korban atau denda restorative.

Dalam penjatuhan sanksi mengikut sertakan pelaku, korban, masyarakat dan para penegak hukum secara aktif. Pelaku bekerja aktif untuk merestore kerugian korban, dan menghadapi korban/ wakil korban. Korban aktif dalam semua tahapan proses dan akan membantu dalam penentuan sanksi bagi si pelaku. Masyarakat terlibat sebagai mediator, membantu korban dan mendukung pemenuhan kewajiban pelaku. Penegak hukum memfasilitasi berlangsungnya mediasi.

b) Rehabilitasi Pelaku

Fokus utama peradilan restorative untuk kepentingan dan membangun secara positif, maka anak dan keluarga merupakan sumber utama. Anak dianggap berkompeten dan mempunyai kemampuan positif, bersifat preventif dan proaktif. Untuk kepentingan rehabilitasi pelaku diperlukan perubahan sikap lembaga kemasyarakatan dan perilaku orang dewasa. Rehabilitasi pelaku dilakukan dengan pelaku yang bersifat learning by doing, konseling dan terapi untuk memotivasi keterlibatan aktif para pihak.

Tujuan rehabilitasi tercapai dilihat pada keadaan apakah pelaku telah memulai halhal positif baru, apakah pelaku diberi kesempatan untuk mempraktekkan dan mendemonstrasikan perilaku patuh norma, apakah stigmatisasi dapat dicegah, apakah telah terjadi perkembangan self image dalam diri pelaku dan public -image dan peningkatan keterikatan pada masyarakat.

Rehabilitasi pelaku dalam bentuk kegiatan praktek agar anak memperoleh pengalaman kerja, dan anak mampu mengembangkan proyek kultural sendiri.

Dalam aspek rehabilitasi ini secara bersama-sama memerlukan peran-peran pelaku, korban, masyarakat dan penegak hukum secara sinergi. Pelaku aktif dalam pengembangan kualitas diri dalam kehidupan masyarakat. Korban memberikan masuk- an pada proses rehabiltasi. Masyarakat mengembangkan kesempatan bagi anak untuk memberikan sumbangan produktif, mengembangkan kompetensi dan rasa memiliki. Penegak hukum peradilan anak mengembangkan peran baru anak pelaku untuk mempratekkan dan mendemonstrasikan kompetensinya, aksesnya dan membangun keterikatan kemitraan dengan masyarakat.

c) Aspek Perlindungan Masyarakat

Asumsi dalam peradilan restorative tentang tercapainya perlindungan masyarakat dengan upaya kolaborasi system peradilan dan masyarakat untuk mengembangkan pencegahan. Penyekapan dibatasi hanya sebagai upaya akhir. Masyarakat bertanggung jawab aktif mendukung terselenggaranya restorasi.

Indikator tercapainya perlindungan masyarakat apabila angka residivis turun, sementara pelaku berada di bawah pengawasan masyarakat, masyarakat merasa aman dan yakin atas peran system peradilan anak, pelibatan sekolah, keluarga dan lembaga kemasyarakatan untuk mencegah terjadinya kejahatan; ikatan social dan reintegrasi meningkat.

Untuk meningkatkan perlindungan masyarakat, maka pelaku, korban, masyarakat dan professional peradilan anak sangat diharapkan perannya. Pelaku harus terlibat secara konstruktif mengembangkan kompetensi dan kegiatan restorative dalam program secara seimbang, mengembangkan kontrol internal dan komitmen dengan teman sebaya dan organisasi anak.

Korban memberikan masukan yang berguna untuk melanjutkan misi perlindungan masyarakat dari rasa takut dan kebutuhan akan pengawasan pelaku delinkuen, dan melindungi bagi korban kejahatan lain.

Masyarakat memberikan bimbingan pada pelaku, dan berperan sebagai mentor dan memberikan masukan bagi peradilan tentang informasi latar belakang terjadinya kejahatan. 
Professional peradilan anak mengembangkan skala insentif dan menjamin pemenuhan kewajiban pelaku dengan pengawasan, membantu sekolah dan keluarga dalam upaya mereka mengawasi dan mempertahankan pelaku tetap di dalam masyarakat.

Indikator dalam peradilan anak restoratif dapat dilihat dari peran-peran: Pelaku; Korban; masyarakat dan Para profesonal peradilan anak. Masing-masing peran sebagai berikut ${ }^{7}$ :

a. Pelaku: pelaku aktif untuk merestore kerugian korban dan masyarakat. la harus menghadapi korban/wakil korban;

b. Korban: akltif terlibat dalam semua tahapan proses dan berperan aktif dalam mediasi dan ikut menentukan sanksi bagi pelaku;

c. Masyarakat: terlibat sebagai mediator mengembangkan pelayanan masyarakat dan menyediakan kesempatan kerja bagi pelaku sebagai wujud kewajiban reparatif, membantu korban dan mendukung pemenuhan kewajiban pelaku;

d. Para profesional: memfasilitasi berlangsungnya mediasi, memberikan jaminan terselenggaranya restoratif, mengembangkan opsi-opsi pelayanan masyarakat secara kreatif/restoratif, melibatkan anggota masyarakat dalam proses, mendidik masyarakat.

\section{Dasar Hukum Ide Peradilan Restoratif dalam Sistem Peradilan Pidana Anak Indonesia}

Tujuan sistem peradilan pidana anak di Indonesia dapat dilihat dalam ketentuan UU Pengadilan Anak (UU No. 3 Tahun 1997). Di dalam konsideran "Menimbang" undang-undang tersebut ditandaskan bahwa pembuatan UU Pengadilan Anak dimaksudkan sebagai ketentuan dalam penyelenggaraan pengadilan bagi anak, di mana terhadap anak perlu perlakuan khusus. Diperlukan perlakuan khusus karena anak sebagai generasi muda yang memiliki peran strategis dan mempunyai ciri khusus, maka memerlukan pembinaan dan perlindungan dalam rangka menjamin pertumbuhan dan perkembangan fisik, mental, sosial secara utuh, selaras, serasi dan seimbang.

Tujuan sistem peradilan pidana anak dalam UUPA, tidak tertulis secara nyata dalam pasal-pasal UUPA, namun dapat diketahui dari ketentuan pasal yang mengatur tentang tugas dan wewenang sidang pengadilan anak, dan dalam "Penjelasan Umum" undang-undang tersebut. Pasal 3 UUPA menentukan:

"Sidang Pengadilan Anak yang selanjutnya disebut Sidang Anak bertugas dan berwenang memeriksa, memutus, dan menyelesaikan perkara anak sebagaimana ditentukan dalam undang-undang ini."

Selanjutnya tujuan sistem peradilan pidana anak berdasar UUPA, dapat diketahui dari kalimat-kalimat dalam "Penjelasan Umum UUPA", sebagai berikut.

"... Mengingat ciri dan sifat yang khas pada anak dan demi perlindungan terhadap anak, maka perkara Anak Nakal, wajib disidangkan pada Pengadilan Anak yang berada di lingkungan Peradilan Umum. Dengan demikian, proses peradilan perkara Anak Nakal dari sejak ditangkap, ditahan, diadili dan pembinaan selanjutnya, wajib dilakukan oleh pejabat khusus yang benar-benar memahami masalah anak.

Dalam penyelesaian perkara Anak Nakal, Hakim wajib mempertimbangkan laporan hasil kemasyarakatan yang dihimpun oleh Pembimbing Kemasyarakatan mengenai data pribadi maupun keluarga dari anak yang bersangkutan. Dengan adanya hasil laporan tersebut, diharapkan Hakim dapat memperoleh gambaran yang tepat untuk memberikan putusan yang seadil-adilnya bagi anak yang bersangkutan.

Putusan hakim akan mempengaruhi kehidupan selanjutnya dari anak yang bersangkutan, oleh sebab itu Hakim harus yakin benar, bahwa putusan yang diambil akan dapat menjadi salah satu dasar kuat untuk mengembalikan dan mengantar anak menuju masa depan yang baik untuk mengembangkan dirinya sendiri sebagai warga negara yang bertanggung jawab bagi kehidupan keluarga, bangsa, dan negara. 
192 Jurnal Dinamika Hukum

Vol. 9 No. 3 September 2009

Untuk lebih memantapkan upaya pembinaan dan pemberian bimbingan bagi Anak Nakal yang telah diputus oleh Hakim, maka anak tersebut ditampung di Lembaga Pemasyarakatan Anak. Berbagai pertimbangan tersebut di atas serta dalam rangka mewujudkan peradilan yang memperhatikan perlindungan dan kepentingan anak, maka perlu diatur ketentuan-ketentuan mengenai penyelenggaraan pengadilan yang khusus bagi anak dalam lingkungan Peradilan Umum.

Kepolisian Negara Indonesia mempunyai fungsi pemerintahan Negara di bidang pemeliharaan keamanan dan ketertiban masyarakat, penegakan hukum, perlindungan, pengayoman dan pelayanan kepada masyarakat. Tugas memelihara keamanan dan ketertiban masyarakat berarti polisi bertugas untuk menjaga ketenangan masyarakat, tugas menegakkan hukum berarti tugas polisi dalam kontek pemberantasan kejahatan, sedangkan tugas polisi memberikan perlindungan, pengayoman dan pelayanan kepada masyarakat dalam hal ini dalam kontek tugas polisi untuk memberikan bantuan kepada masyarakat. Berdasarkan kebijakan formulasi dalam UU No. 2 Tahun 2002 tersebut, tampak bahwa kewenangan kepolisian dalam kontek implementasi peradilan restoratif, yaitu kepolisian berwenang untuk mengadakan penghentian penyidikan dan berwenang untuk mengadakan tindakan lain menurut hukum yang bertanggung jawab, serta dengan adanya tugas polisi memberikan perlindungan, pengayoman dan pelayanan kepada masyarakat dalam hal ini dalam kontek tugas polisi untuk memberikan bantuan kepada masyarakat, maka kepolisian dapat bertindak menurut penilaiannya sendiri. Di dalam fungsi kepolisian sebagai pengayom, pelindung dan pelayan masyarakat, dan dalam fungsi polisi dalam penegakan hukum, menurut penulis polisi dapat menggunakan diskresi polisi untuk tidak meneruskan perkara Anak Nakal ke sidang pengadilan, dan menyelesaikan perkara Anak Nakal tersebut dengan program peradilan restoratif.

Polisi secara universal mempunyai suatu otoritas legal yang disebut "Diskresi" (dis- cretionary power), di mana dengan otoritas tersebut polisi berwenang untuk meneruskan tidak meneruskan suatu perkara berdasarkan penilaiannya sendiri. Otoritas diskresi kepolisian di Indonesia, diakomodasi dalam Pasal 16 ayat (1) huruf I, ayat (2) dan Pasal 18 UU Nomor 2 tahun 2002 tentang Kepolisian Negara Republik Indonesia.

Ketentuan Pasal 16 ayat (1) huruf I UU Kepolisian Negara Republik Indonesia ini mengatur tentang yang dapat dilakukan oleh kepolisian sehubungan dengan tugas pokok kepolisian dibidang proses pidana, yaitu: "mengadakan tindakan lain menurut hukum yang bertanggung jawab". Tindakan lain ini dengan melihat syarat-syarat tertentu yaitu: tidak bertentangan dengan suatu aturan hukum; selaras dengan kewajiban hukum yang mengharuskan tindakan tersebut dilakukan; harus patut, masuk akal dan termasuk dalam lingkungan jabatannya; pertimbangan yang layak berdasarkan keadaan yang memaksa; dan menghormati hak asasi manusia.

Ketentuan Pasal 18 UU No 2 tahun 2002, mengatur sebagai berikut.

1) Untuk kepentingan umum pejabat kepolisian negara Republik Indonesia dalam melaksanakan tugas dan wewenangnya dapat bertindak menurut penilaiannya sendiri (garis bawah dari penulis);

2) Pelaksanaan ketentuan sebagaimana ayat (1) hanya dapat dilakukan dengan memperhatikan peraturan perundang-undangan serta kode etik Profesi Kepolisian Negara Republik Indonesia.

Di dalam Penjelasan Pasal 18 ayat (1) dijelaskan:

"Yang dimaksud dengan bertindak menurut penilaiannya sendiri, adalah suatu tindakan yang dapat dilakukan oleh anggota Kepolisian Negara Republik Indonesia yang dalam bertindak harus mempertimbangkan manfaat serta resiko dari tindakannya dan betul-betul untuk kepentingan umum. ${ }^{8}$

8 Sehubungan dengan tugas Polri dalam kebijakan kriminal (kebijakan operasional dalam upaya penanggulangan kejahatan), maka seperti yang dikemukakan oleh Barda Nawawi Arief, Polri dapat saja menentukan langkah-langkah kebijakan yang sebaiknya 
Saat ini terdapat kebijakan dari Kabareskrim Polri dan dari Kapolda Jawa Tengah sehubungan dengan penanganan terhadap anak yang berhadapan dengan hukum baik sebagai pelaku maupun sebagai saksi/korban, untuk menerapkan restorative justice, berdasarkna Surat Telegram Rahasia dari Kabareskrim Polri No. Pol. TR/359/DIT.I/VI/2008 tanggal 9 Juni 2008 yang ditujukan kepada Para KAPOLDA UP.DIR RESKRIM, dan Surat Telegram Rahasia dari Kapolda Jateng No.Pol. STR/215/III/2009, tanggal 30 Maret 2009 yang ditujukan kepada: KAPOLWILTABES SEMARANG, KAPOLWIL JAJARAN POLDA JATENG, KAPOLTABES SURAKARTA, dan KAPOLRES/TA JAJARAN POLDA JATENG.

$$
\text { Surat Telegram Rahasia dari }
$$

KABARESKRIM POLRI No. Pol. TR/395/DIT.I/VI/

2008, isinya antara lain sebagai berikut.

1) tindak pidana yang dapat dialihkan secara diversi dengan diskusi komprehensif atau restorative justice, dilakukan berdasarkan hasil litmas dari bapas, merupakan tindak pidana biasa, mendapatkan maaf dari korban, komponen masyarakat dengan atau tanpa syarat, dalam bentuk formal, mediasi dan musyawarah secara kekeluargaan.

2) tindak pidana yang tidak dapat dialihkan, merupakan tindak pidana berat seperti pembunuhan, pencurian dengan pemberatan, pencurian dengan kekerasan, perkosaan, penganiayaan dengan korban luka berat atau mati, pengedar narkotika, senjata api dan terorisme.

3) Setelah dilakukan diversi atau restorative justice oleh penyidik, anak yang berhadapan dengan hukum dikembalikan kepada orang tua/wali, apabila orang tua/wali tidak sanggup membina, maka anak yang berhadapan dengan hukum dapat direkomendasikan untuk dibina di panti milik depsos/dinsos setempat.

4) Sedapat mungkin mengembangkan prinsip diversi dalam model restoratif justice guna memproses perkara pidana yang dilakukan

diambil dalam melaksanakan tugas dan wewenangnya . Lihat Barda Nawawi Arief, 2007, Masalah Penegakan Hukum dan Kebijakan Hukum Pidana dalam Penanggulangan Kejahatan, Jakarta: Kencana Prenada Media Group, hlm. 52 oleh anak dengan membangun pemahaman dalam komunitas setempat bahwa keterlibatan anak dalam tindak pidana harus dipahami sebagai kenakalan anak akibat kegagalan/kesalahan orang dewasa dalam mendidik dan mengawal anak sampai usia dewasa. Tindak pidana anak harus dipandang sebagai pelanggaran terhadap manusia dan relasi antar manusia sehingga memunculkan kewajiban dari semua pihak/ seluruh komponen masyarakat untuk terus berusaha dan membuat segala sesuatunya menjadi lebih baik melalui pelibatan semua pihak untuk ambil peran guna mencari solusi terbaik, baik untuk kepentingan pihak-pihak yang menjadi korban dan bagi kepentingan anak sebagai pelaku dimasa sekarang dan masa akan datang. Dengan cara demikian diharapkan setiap tindak pidana yang melibatkan anak dapat diproses dengan pendekatan restoratif justice sehingga menjauhkan anak dari proses hukum formal/pengadilan agar anak terhindar dari trauma psikologis dan stigmatisasi serta dampak buruk lainnya sebagai ekses penegakan hukum formal/ pengadilan.

5) Setelah dilakukan diversi atau restoratif justice oleh penyidik, dikembalikan kepada orang tua/wali, jika ortu tidak sanggup membina, anak berhadapan dengan hukum dapat direkomendasikan untuk dibina di panti milik departemen sosial /dinas sosial.

3. Pelaksanaan Praktik Mediasi Pelaku dan Korban dalam Proses Peradilan Anak di Wilayah Hukum Balai Pemasyarakatan Purwokerto

a. Jenis dan Jumlah Perkara Anak Nakal/ Klien di Wilayah Hukum Bapas Purwokerto

Hasil penelitian di lokasi penelitian, jenis dan jumlah perkara anak nakal yang terdapat dalam dokumen BAPAS Purwokerto9 disajikan dalam tabel sebagai berikut

BAPAS Purwokerto yang meliputi Wilayah Hukum PN Purwokerto, Purbalingga , Banyumas, Banjarnegara, Cilacap, Kebumen, Purworejo. 
194 Jurnal Dinamika Hukum

Vol. 9 No. 3 September 2009

Tabel 2

Jenis dan Jumlah Perkara Anak Nakal/Klien Bapas Purwokerto

\begin{tabular}{|c|l|c|c|}
\hline No & Jenis Kejahatan & Jumlah & Prosentase \\
\hline 1 & Pencurian & 520 & 56,79 \\
\hline 2 & Penganiayaan & 172 & 18,26 \\
\hline 3 & Pembunuhan & 5 & 0,55 \\
\hline 4 & Kesusilaan & 95 & 9,79 \\
\hline 5 & Pemerasan & 25 & 2,77 \\
\hline 6 & Narkoba & 27 & 3 \\
\hline 7 & Lakalantas & 38 & 3,78 \\
\hline 8 & $\begin{array}{l}\text { Membawa Senjata } \\
\text { tajam }\end{array}$ & 3 & 0,33 \\
\hline 9 & Pengrusakan & 12 & 0,77 \\
\hline 10 & Penipuan & 7 & 0,77 \\
\hline 11 & Perjudian & 12 & 1,33 \\
\hline 12 & Uang Palsu & 2 & 0,22 \\
\hline 13 & Penggelapan & 4 & 0,44 \\
\hline 14 & Kebakaran & 3 & 0,33 \\
\hline 15 & $\begin{array}{l}\text { Penghinaan/pencem } \\
\text { aran massal }\end{array}$ & 3 & 0,33 \\
\hline 16 & $\begin{array}{l}\text { Melarikan perempu- } \\
\text { an di bawah umur }\end{array}$ & 4 & 0,44 \\
\hline & Jumlah & 932 & $100 \%$ \\
\hline
\end{tabular}

Sumber: Dokumen di BAPAS Purwokerto yang diolah, dari tahun 2002 sampai Desember 2008

Berdasarkan Tabel 2 diketahui bahwa jumlah perkara Anak Nakal di wilayat BAPAS Purwokerto ada 932 perkara, dengan jenis perkara yang terbanyak adalah tindak pidana pencurian, penganiayaan, kesusilaan, tindak pidana lalu lintas, narkoba maupun tindak pidana pemerasan. Dari sejumlah perkara tersebut, tidak semua dilimpahkan ke penuntutan ataupun diperiksa pengadilan.

Mencermati data pada Tabel 3 ini, tampak bahwa sebenarnya permintaan atau saran dari BAPAS ke arah mediasi cukup banyak, yaitu:

1) permintaan kembali pada orang tua, berjumlah 58 (empat puluh delapan);

2) perdamaian/non-litigasi, berjumlah 59

(empat puluh sembilan).

Dengan demikian saran dari BAPAS yang mengarah pada implementasi mediasi berjumlah 97 perkara $(10,77 \%)$ dari 898 perkara. Hal ini menandakan sebenarnya BAPAS telah memberikan peluang untuk implementasi mediasi tersebut, yang diharapkan menjadi
Tabel 3

Jenis Sanksi Yang Disarankan Bapas dan Jumlah Litmas Klien Bapas Purwokerto Tahun 20022008

\begin{tabular}{|c|l|c|c|}
\hline No. & $\begin{array}{l}\text { Jenis Sanksi yang } \\
\text { disarankan Bapas untuk } \\
\text { Klien }\end{array}$ & Jumlah & Prosentase \\
\hline 1 & Pidana bersyarat & 129 & 13,81 \\
\hline 2 & $\begin{array}{l}\text { Pidana dengan pembim- } \\
\text { bingan/ pengawasan }\end{array}$ & 264 & 29,38 \\
\hline 3 & $\begin{array}{l}\text { Pidana sesuai dengan } \\
\text { perbuatan }\end{array}$ & 219 & 23,26 \\
\hline 4 & $\begin{array}{l}\text { Pidana dengan memper- } \\
\text { hatikan masa penahanan } \\
\text { yang telah dijalani }\end{array}$ & 171 & 19,04 \\
\hline 5 & $\begin{array}{l}\text { Pendidikan Paksa ke } \\
\text { Negara }\end{array}$ & 16 & 1,77 \\
\hline 6 & Kembali ke Orang tua & 58 & 5,33 \\
\hline 7 & $\begin{array}{l}\text { Kekeluargaaan/ perda- } \\
\text { maian atau Non-Litigasi } \\
\text { yang disaksikan oleh } \\
\text { Bapas dan Kepolisian }\end{array}$ & 59 & 5,44 \\
\hline 8 & Pelimpahan ke Bapas lain & 16 & 1,77 \\
\hline & Jumlah & 932 & $100 \%$ \\
\hline
\end{tabular}

Sumber: Dokumen di BAPAS Purwokerto yang diolah, dari tahun 2002 sampai Desember 2008

pertimbangan bagi penyidik anak, penuntut umum anak maupun hakim anak. Namun demikian dari jumlah tersebut, tidak semua diputus sesuai dengan permintaan/saran Bapas. Hal ini dapat dilihat dalam Tabel III sebagai berikut.

Tabel 4

Jenis dan Jumlah Putusan dan Penyelesaian Perkara Anak yang Diterima Bapas Purwokerto Tahun 2002-2008

\begin{tabular}{|c|l|c|c|}
\hline No. & Jenis Putusan & Jumlah & Prosentase \\
\hline 1 & Pidana bersyarat & 42 & 6,86 \\
\hline 2 & $\begin{array}{l}\text { Pidana sesuai dengan per- } \\
\text { buatan, pidana pendidikan } \\
\text { paksa ke Negara }\end{array}$ & 543 & 85,45 \\
\hline 3 & Kembali ke Orang Tua & 1 & 0,17 \\
\hline 4 & $\begin{array}{l}\text { Kekeluargaaan/ perdamai- } \\
\text { an atau Non-Litigasi yang } \\
\text { disaksikan oleh Bapas dan } \\
\text { Kepolisian }\end{array}$ & 60 & 7,52 \\
\hline & Jumlah & 646 & $100 \%$ \\
\hline
\end{tabular}

Sumber: Dokumen di BAPAS Purwokerto yang diolah, dari Tahun 2002 sampai Desember 2008.

Selama 2002 sampai Agustus 2008 jumlah perkara anak yang disarankan untuk diselesaikan baru berjumlah 612 perkara, sedang sisanya (286 perkara) ketika dilakukan penelitian 
belum ada putusan. Selain itu sisa perkara tersebut belum diketahui putusannya oleh Bapas, karena terdapat putusan yang tidak disampaikan ke BAPAS.

Perkara yang disarankan diselesaikan secara kekeluargaan/perdamaian atau nonlitigasi yang disaksikan oleh BAPAS dan Kepolisian ini, yaitu dari jumlah 49 perkara ini, perkaranya dihentikan dan tidak dilakukan penuntutan berjumlah 46 perkara. dan yang disarankan agar kembali pada orang tuanya berjumlah 48 perkara. Perkara yang disarankan agar kembali pada orang tua 48 perkara, ternyata hanya 1 perkara yang diputus oleh hakim dengan putusan kembali pada orang tua, yaitu dalam perkara kejahatan kesusilaan. Pidana bersyarat dan pidana pembimbingan/pengawasan yang disarankan berjumlah 389 perkara, hanya diputus pidana bersyarat berjumlah 42 . Dengan demikian selebihnya perkara tersebut diputus pidana penjara.

Adapun jenis-jenis perkara yang dilakukan penyelesaian secara kekeluargaan/damai atau non litigasi, dilihat dalam tabel berikut ini.

Tabel 5

Jenis dan Jumlah Kasus yang Diselesaikan Secara Kekeluargaan/ Damai atau Non-Litigasi di Bapas Purwokerto yang Disaksikan oleh Pihak Kepolisian Tahun 2002-2008.

\begin{tabular}{|c|l|c|c|}
\hline No. & Jenis Kejahatan & Jumlah & Prosentase \\
\hline 1 & Pencurian & 19 & 32,62 \\
\hline 2 & Penganiayaan & 26 & 47,82 \\
\hline 3 & Pembunuhan & - & \\
\hline 4 & Kesusilaan & - & \\
\hline 5 & Pemerasan & - & \\
\hline 6 & Narkoba & - & \\
\hline 7 & Lakalantas & - & \\
\hline 8 & Membawa Senjata tajam & - & \\
\hline 9 & Pengrusakan barang & 15 & 19,56 \\
\hline 10 & Penipuan & - & \\
\hline 11 & Perjudian & - & \\
\hline & Jumlah & 60 & $100 \%$ \\
\hline
\end{tabular}

Sumber: Dokumen di BAPAS Purwokerto yang diolah, dari Tahun 2002 sampai Desember 2008

Perkara-perkara yang diselesaikan secara kekeluargaan terdiri dari tindak pidana pencurian, penganiayaan dan pengrusakan barang.
Untuk perkara-perkara lain tampak belum pernah dilakukan penyelesaian secara damai dalam tahap penyidikan.

b. Pertimbangan Penyelesaian secara Mediasi/ Perdamaian dalam Perkara Anak di Wilayah Hukum Balai Pemasyarakatan Purwokerto

Implementasi Mediasi di lokasi penelitian dalam beberapa perkara jika terdapat kondisikondisi, sebagai berikut.

1) terhadap pelaku masih pelajar, tetap menangkap tetapi dinasihati;

2) apabila pelaku dan korban saling memaafkan dan diberi ganti rugi, maka perkara sering kali dihentikan;

3) jika anak menyesal dan berjanji tidak akan mengulangi serta orang tua sanggup membimbing, maka polisi perkara dihentikan dan pelaku dikembalikan orang tua. ${ }^{10}$

Selain hal itu, maka pihak kepolisian dapat menyetujui implementasi mediasi dalam perkara anak yang terdapat kondisi-kondisi tertentu. Kondisi-kondisi tertentu dalam hal ini misalnya :

1) kejahatan tersebut ringan;

2) masyarakat tidak berontak ;

3) antara pelaku-korban telah damai;

4) orang tua pelaku sanggup membimbing;

5) kondisi lingkungan dapat menerima anak tersebut, serta

6) pelaku anak tersebut bukan residivis anak. $^{11}$

Dalam praktik penyelesaian perdamaian secara kekeluargaan dalam perkara pidana dilakukan atau terjadi, karena pada umumnya pelaku atau keluarga pelaku meminta kepada kepada penyidik agar perkara tidak diproses lebih lanjut. ${ }^{12}$ Pihak pelaku/keluarga pelaku pada umumnya telah memberikan ganti rugi kepada pihak korban, sehingga hal ini sebagai upaya mengambil hati pihak korban agar tidak menuntut lebih lanjut. Pihak korban/keluarga korban menyatakan telah mengadakan per-

10 Hasil pengamatan dan wawancara di lokasi penelitian.

11 Hasil pengamatan dan wawancara di lokasi penelitian.

12 Uraian ini dan selanjutnya adalah hasil dari Wawancara dengan Penyidik anak di Polres Banyumas, Purbalingga., Kebumen, dan Cilacap. 
196 Jurnal Dinamika Hukum

Vol. 9 No. 3 September 2009

temuan sendiri antara korban (keluarga korban) dengan pelaku (keluarga pelaku), dan korban membawa surat pernyataan tentang telah ada perdamaian antara korban dengan pelaku. Selanjutnya korban menyampaikan kepada penyidik bahwa telah ada penyelesaian untuk tidak dilanjutkan, atau dengan kata lain kasus dimohon agar dicabut.

Perkara anak yang dilakukan perdamaian ini, karena terdapat suatu keadaan bahwa antara pelaku dan korban biasanya sudah sangat mengenal sehingga terdapat kedekatan emosional antara pelaku/keluarga pelaku dan korban/keluarga korban, dan tindak pidana yang dilakukan adalah biasanya berupa: penganiayaan; penipuan; pencemaran dan penggelapan, dan tindak pidana kesusilaan secara limitatif. Untuk tindak pidana kesusilaan ini secara limitatif yaitu "Melarikan anak perempuan di bawah umur “ sebagaimana diatur dalam Pasal 332 KUHP.

Keikutsertaan pihak penyidik dalam penyelesaian secara damai dan non-litigasi ini, dalam hal ini berupa:

1) penyidik (polisi) mempertemukan antara pelaku dan korban atau pihak keluarga korban;

2) penyidik memberi kelonggaran (jangka waktu) terhadap pelaku dan korban untuk melakukan musyawarah;

3) penyidik akan mengabulkan atau tidak mengabulkan perdamaian antara pelaku dan korban, akan tetap melihat pertimbangan kepentingan atau kemanfaatan bagi masyarakat dan kondisi nyata antara pelaku dan korban;

4) penyidik akan menghentikan atau tidak meneruskan pelimpahan perkara anak tingkat penuntutan, jika terdapat keadaan seperti:

a) aduan dicabut;

b) tidak cukup bukti;

c) korban telah diberi ganti rugi;

d) karena ada saran dari tokoh masyarakat;

e) ada arahan dari pimpinan agar perkara dihentikan.

Dengan uraian di atas tentang implementasi mediasi dalam praktik penyidikan di lokasi penelitian, dalam bentuk penyelesaian secara Non-Litigasi yang berupa penyelesaian perdamaian secara keluargaan dan selanjutnya pelakunya atau keluarganya untuk memberikan ganti rugi, saling memaafkan ataupun perbuatan yang harus dilakukan sesuai dengan hasil musyawarah, misalnya pihak keluarga diwajibkan membimbing anak pelaku tindak pidana tersebut.

Pihak BAPAS telah mengimplementasikan mediasi, yaitu apabila diperhatikan tentang saran-saran BAPAS dalam laporan Penelitian Kemasyarakatan. Pihak BAPAS akan mengajukan saran berupa tindakan agar anak dikembalikan pada orangtuanya, apabila terdapat kondisi-kondisi yang melekat pada kasus yang bersangkutan, seperti:

1) kondisi anak masih muda;

2) anak perlu sekolah;

3) orang tuanya sanggup membimbing;

4) tindak pidana termasuk ringan;

5) pihak korban sudah diberi ganti rugi dan memaafkan;

6) kondisi lingkungan masyarakat sekitarnya dinilai layak;

7) untuk pembinaan anak tersebut.

Penyelesaian secara non-litigasi dalam perkara pidana merupakan jalur alternatif, di samping jalur utama yaitu : jalur litigasi. Jalur non-litigasi sebenarnya tidak terdapat dalam aturan pokok hukum acar pidanan, yaitu KUHAP. Namun demikian dalam kenyataannya keberadaan non-litigasi diakui oleh masyarakat sehingga digunakan.sebagai salah satu cara penyelesaian perkara pidana. Ada beberapa hal yang menjadikan penyelesaian perkara pidana melalui jalur non-litigasi. Pertama, adalah adanya kesepakatan antara para pihak untuk menyelesaikan perkara pidana, baik melalui peradilan pada tahap pertama (kepolisian) maupun tidak melalui peradilan. Kedua, adanya kesepakatan pula untuk menggunakan atau tidak menggunakan jasa seorang atau beberapa orang mediator. Ketiga, dalam proses itu terjadi negosiasi atau tawar menawar mengenai jumlah ganti rugi atau tindakan lain yang harus diberikan atau dilakukan oleh pelaku kejahatan kepada pihak korban. Proses 
negosiasi atau tawar menawar ini merupakan proses yang biasanya terdapat dalam hukum perdata.

Kedudukan pelaku dalam proses penyelesaian perkara pidana jalur non-litigasi ini berbeda dengan proses melalui jalur litigasi. Pada jalur litigasi, kepada pelaku dikenakan asas praduga tak bersalah (presumtion of innocence), sedang jalur non-litigasi kedudukan pelaku adalah praduga bersalah (presumtion of guilty). Pada jalur non-litigasi terjadi negosiasi dan bukan mencari kesalahan pelaku, akan tetapi menentukan apa yang harus dilakukan atau diberikan oleh pelaku kepada korban atau keluarganya.

Untuk memperoleh gambaran tentang model penyelesaian perkara pidana melalui jalur non-litigasi, di bawah ini akan gambarkan model tersebut dan penjelasannya. Yang pokok bahwa penyelesaian perkara pidana melalui jalur non-litigasi dapat dilakukan di luar peradilan pidana dan di dalam peradilan pidana. Penyelesaian non-litigasi yang dilakukan di luar peradilan pidana berarti perkara pidana tersebut belum dilaporkan atau diadukan ke kepolisian, sehingga tidak ada campur tangan kepolisian. Semua kendali penyelesaian perkara di sini ada para pihak. Pada penyelesaian non-litigasi yang dilakukan di dalam kerangka peradilan pidana (tingkat kepolisian), berarti perkara tersebut sudah dilaporkan atau diadukan ke kepolisian dan masuk dalam daftar register. Dalam proses ini, polisi dapat bertindak selaku mediator atau dapat menunjuk pihak ketiga selaku mediator. Apabila yang menjadi mediator adalah pihak ketiga, maka polisi memantau jalannya proses perdamaian sampai selesai untuk kemudian dicatat pada daftar register bahwa perkara tersebut telah dilakukan penyelesaian.

Apabila proses penyelesaian sengketa terjadi di luar pengadilan dan tidak melibatkan pihak ketiga sebagai mediator, maka negosiasi dilakukan oleh korban atau keluarganya dan pelaku atau keluarganya. Negosiasi merupakan komunikasi dua arah yang dirancang untuk mencapai kesepakatan di antara dua pihak yang berselisih. Dalam negosiasi itu diperbicangkan atau ditawarkan penyelesaian oleh masingmasing pihak dengan mempertimbangkan segala kemampuan yang ada pada diri masingmasing pihak si pelaku kejahatan untuk mengganti kerugian atau melakukan kegiatan tertentu sebagai pengganti uang. Jika proses negosiasi berhasil, maka perkara tersebut selesai dengan kesepakatan.

Jika proses negosiasi tidak dapat dicapai kata sepakat -masih di luar pengadilan- dapat digunakan jasa pihak ketiga sebagai mediator. Mediator ini yang selanjutnya akan memandu atau mencari cara penyelesaian yang dapat diterima oleh masing-masing pihak. Mediator melakukan mediasi kepada pihak-pihak yang akan berselisinn tersebut dan kemudian mempertemukan masing-masing pendapat serta menawarkan jalan ke luar yang baik dan dapat ditempuh. Di dalam mediasi, mediatorlah yang mengontrol proses negosiasi, namun mediator tidak membuat keputusan dan hanya memfasilitasi saja. ${ }^{13}$ Jika mediasi gagal, maka perkara tersebut dapat dibiarkan saja sehingga tidak ada penyelesaian, dan dapat pula dilaporkan atau diadukan kepada kepolisian. Pihak kepolisian setelah menerima laporan, jika polisi tersebut termasuk yang kontra dengan penyelesaian melalui jalur non-litigasi, maka penyelesaiannya selanjutnya adalah sesuai dengan ketentuan KUHAP, yaitu dilakukan pemeriksaan dan dibuat Berita Acara Pemeriksaan. Apabila polisi yang menerima laporan termasuk yang pro dengan penyelesaian non-litigasi, maka dengan melihat karakteristik kasus yang dihadapi, maka polisi tersebut akan menawarkan kepada pihak-pihak yang berselisih untuk diselesaikan secara damai atau kekeluargaan, dan polisi dapat sebagai mediator atau polisi menunjuk pihak lain menjadi mediator. Jika proses negosiasi yang difasilitasi oleh mediator yang bukan polisi, maka polisi bertindak sebagai pengawas dan menerima laporan hasil negosiasi.

Jika proses mediasi berjalan dengan baik dan menghasilkan kesepakatan, maka perkara

13 Leonard L Riskin \& James E. Westbrook, 1987, Dispute Resolution and Lawyers, St. Paul: West Publishing Co. 
198 Jurnal Dinamika Hukum

Vol. 9 No. 3 September 2009

pidana tersebut selesai. Namun jika mediasi gagal, maka perkara selanjutnya diteruskan pada proses penyelesaian perkara melalui jalur litigasi. Hal ini berarti perkara tersebut dilanjutkan ke sidang persidangan di muka hakim. Hakimlah yang akan membuat keputusan bersalah atau tidak bersalahnya si pelaku kejahatan tersebut.

\section{Praktek Mediasi sebagai Implementasi Model Peradilan Restoratif dalam Sistem Peradilan Anak Di Wilayah Hukum Balai Pemasyarakatan Purwokerto}

Sistem peradilan pidana anak dengan paradigma restoratif, di dalam mencapai tujuan penjatuhan sanksi, maka diikut sertakan korban untuk berhak aktif terlibat dalam proses peradilan. Indikator pencapaian tujuan penjatuhan sanksi tercapai dengan dilihat pada apakah korban telah direstorasi, kepuasan korban, besarnya ganti rugi, kesadaran pelaku atas perbuatannya, jumlah kesepakatan perbaikan yang dibuat, kualitas pelayanan kerja dan keseluruhan proses yang terjadi. Bentukbentuk sanksi yaitu restitusi, mediasi pelaku korban, pelayanan korban, restorasi masyarakat, pelayanan langsung pada korban atau denda restorative.

Dalam penjatuhan sanksi mengikut sertakan pelaku, korban, masyarakat dan para penegak hukum secara aktif. Pelaku bekerja aktif untuk merestore kerugian korban, dan menghadapi korban/ wakil korban. Korban aktif dalam semua tahapan proses dan akan membantu dalam penentuan sanksi bagi si pelaku. Masyarakat terlibat sebagai mediator, membantu korban dan mendukung pemenuhan kewajiban pelaku. Penegak hukum memfasilitasi berlangsungnya mediasi.

Fokus utama peradilan restorative untuk kepentingan dan membangun secara positif, maka anak dan keluarga merupakan sumber utama. Anak dianggap berkompeten dan mempunyai kemampuan positif, bersifat preventif dan proaktif. Untuk kepentingan rehabilitasi pelaku diperlukan perubahan sikap lembaga kemasyarakatan dan perilaku orang dewasa. Rehabilitasi pelaku dilakukan dengan pelaku yang bersifat learning by doing, konseling dan terapi untuk memotivasi keterlibatan aktif para pihak.

Tujuan rehabilitasi tercapai dilihat pada keadaan apakah pelaku telah memulai hal-hal positif baru, apakah pelaku diberi kesempatan untuk mempraktekkan dan mendemonstrasikan perilaku patuh norma, apakah stigmatisasi dapat dicegah, apakah telah terjadi perkembangan self image dalam diri pelaku dan public image dan peningkatan keterikatan pada masyarakat. Rehabilitasi pelaku dalam bentuk kegiatan praktek agar anak memperoleh pengalaman kerja, dan anak mampu mengembangkan proyek kultural sendiri. Dalam aspek rehabilitasi ini secara bersama-sama memerlukan peran-peran pelaku, korban, masyarakat dan penegak hukum secara sinergi. Pelaku aktif dalam pengembangan kualitas diri dalam kehidupan masyarakat. Korban memberikan masukan pada proses rehabiltasi. Masyarakat mengembangkan kesempatan bagi anak untuk memberikan sumbangan produktif, mengembangkan kompetensi dan rasa memiliki. Penegak hukum peradilan anak mengembangkan peran baru anak pelaku untuk mempratekkan dan mendemonstrasikan kompetensinya, aksesnya dan membangun keterikatan kemitraan dengan masyarakat.

Asumsi dalam peradilan restorative tentang tercapainya perlindungan masyarakat dengan upaya kolaborasi system peradilan dan masyarakat untuk mengembangkan pencegahan. Penyekapan dibatasi hanya sebagai upaya akhir. Masyarakat bertanggung jawab aktif mendukung terselenggaranya restorasi. Indikator tercapainya perlindungan masyarakat apabila angka residivis turun, sementara pelaku berada di bawah pengawasan masyarakat, masyarakat merasa aman dan yakin atas peran system peradilan anak, pelibatan sekolah, keluarga dan lembaga kemasyarakatan untuk mencegah terjadinya kejahatan; ikatan social dan reintegrasi meningkat.

Untuk meningkatkan perlindungan masyarakat, maka pelaku, korban, masyarakat dan professional peradilan anak sangat diharapkan perannya. Pelaku harus terlibat secara 
konstruktif mengembangkan kompetensi dan kegiatan restorative dalam program secara seimbang, mengembangkan kontrol internal dan komitmen dengan teman sebaya dan organisasi anak. Korban memberikan masukan yang berguna untuk melanjutkan misi perlindungan masyarakat dari rasa takut dan kebutuhan akan pengawasan pelaku delinkuen, dan melindungi bagi korban kejahatan lain. Masyarakat memberikan bimbingan pada pelaku, dan berperan sebagai mentor dan memberikan masukan bagi peradilan tentang informasi latar belakang terjadinya kejahatan.

Professional peradilan anak mengembangkan skala insentif dan menjamin pemenuhan kewajiban pelaku dengan pengawasan, membantu sekolah dan keluarga dalam upaya mereka mengawasi dan mempertahankan pelaku tetap di dalam masyarakat.

Pelaksanaan peradilan restoratif dapat dilakukan melalui kegiatan-kegitan seperti: Mediasi korban dengan pelaku/pelanggar; Musyawarah kelompok keluarga; Pelayanan di masyarakat yang bersifat pemulihan baik bagik korban maupun pelaku

Tujuan sistem peradilan pidana anak di Indonesia dapat dilihat dalam ketentuan UU Pengadilan Anak (UU No. 3 tahun 1997). Di dalam konsideran "Menimbang" undang-undang tersebut ditandaskan bahwa pembuatan UU Pengadilan Anak dimaksudkan sebagai ketentuan dalam penyelenggaraan pengadilan bagi anak, di mana terhadap anak perlu perlakuan khusus. Diperlukan perlakuan khusus karena anak sebagai generasi muda yang memiliki peran strategis dan mempunyai ciri khusus, maka memerlukan pembinaan dan perlindungan dalam rangka menjamin pertumbuhan dan perkembangan fisik, mental, sosial secara utuh, selaras, serasi dan seimbang.

Tujuan sistem peradilan pidana anak dalam UU Pengadilan Anak, tidak tertulis secara nyata dalam pasal-pasal UUPA, namun dapat diketahui dari ketentuan pasal yang mengatur tentang tugas dan wewenang sidang pengadilan anak, dan dalam "Penjelasan Umum" undang-undang tersebut. Pasal 3 UUPA menentukan:
"Sidang Pengadilan Anak yang selanjutnya disebut Sidang Anak bertugas dan berwenang memeriksa, memutus, dan menyelesaikan perkara anak sebagaimana ditentukan dalam undang-undang ini."

Selanjutnya tujuan sistem peradilan pidana anak berdasar UUPA, dapat diketahui dari kalimat-kalimat dalam "Penjelasan Umum UUPA", sebagai berikut:

"... Mengingat ciri dan sifat yang khas pada anak dan demi perlindungan terhadap anak, maka perkara Anak Nakal, wajib disidangkan pada Pengadilan Anak yang berada di lingkungan Peradilan Umum. Dengan demikian, proses peradilan perkara Anak Nakal dari sejak ditangkap, ditahan, diadili dan pembinaan selanjutnya, wajib dilakukan oleh pejabat khusus yang benar-benar memahami masalah anak.

Dalam penyelesaian perkara Anak Nakal, Hakim wajib mempertimbangkan laporan hasil kemasyarakatan yang dihimpun oleh Pembimbing Kemasyarakatan mengenai data pribadi maupun keluarga dari anak yang bersangkutan. Dengan adanya hasil laporan tersebut, diharapkan Hakim dapat memperoleh gambaran yang tepat untuk memberikan putusan yang seadiladilnya bagi anak yang bersangkutan.

Putusan hakim akan mempengaruhi kehidupan selanjutnya dari anak yang bersangkutan, oleh sebab itu Hakim harus yakin benar, bahwa putusan yang diambil akan dapat menjadi salah satu dasar kuat untuk mengembalikan dan mengantar anak menuju masa depan yang baik untuk mengembangkan dirinya sendiri sebagai warga negara yang bertanggung jawab bagi kehidupan keluarga, bangsa, dan negara."

Dengan demikian, Pengadilan Anak diharapkan memberikan arah yang tepat dalam pembinaan dan perlindungan terhadap anak."

Peradilan restoratif untuk menghasilkan keadilan restoratif, yaitu suatu proses dimana semua pihak yang terlibat dalam suatu tindak pidana tertentu bersama-sama memecahkan masalah bagaimana menangani akibatnya di masa yang akan datang. Tindak pidana yang dilakukan anak adalah suatu pelanggaran terhadap manusia dan relasi antar manusia. 
200 Jurnal Dinamika Hukum

Vol. 9 No. 3 September 2009

Tindak pidana menciptakan suatu kewajiban untuk membuat segala sesuatunya menjadi lebih baik dengan melibatkan korban, pelaku dan masyarakat dalam mencari solusi untuk memperbaiki, rekonsiliasi dan menenteramkan hati .

Prinsip-prinsip peradilan restoratif berbeda dengan model peradilan konvensional, yaitu:

1) Membuat pelanggar bertanggung jawab untuk memperbaiki kerugian yang ditimbulkan untuk memperbaiki kerugian yang ditimbulkan oleh kesalahannya;

2) Memberikan kesempatan kepada pelanggar untuk membuktikan kapasitas dan kualitasnya di samping mengatasi rasa bersalahnya secara konstruktif

3) Melibatkan para korban, orang tua, keluarga, sekolah dan teman sebaya;

4) Menciptakan forum untuk bekerja sama dalam menyelesaikan masalah;

5) Menetapkan hubungan langsung dan nyata antara kesalahan dengan reaksi sosial yang formal.

Pelaksanaan peradilan restoratif dapat dilakukan melalui kegiatan-kegitan seperti: Mediasi korban dengan pelaku/pelanggar; Musyawarah kelompok keluarga; Pelayanan di masyarakat yang bersifat pemulihan baik bagik korban maupun pelaku.

Pelaksanaan model peradilan restoratif dapat dilihat dari segi peran pelaku kejahatan tersebut. Peran Pelaku dalam Pelaksanaan model peradilan restoratif dalam sistem peradilan anak, sebagai berikut.

1) Pelaku aktif untuk merestore kerugian korban dan masyarakat.

2) Pelaku harus menghadapi korban/wakil korban;

3) Pelaku bertanggung jawab untuk memperbaiki kerugian yang ditimbulkan untuk memperbaiki kerugian yang ditimbulkan oleh kesalahannya;

4) Pelaku diberi kesempatan untuk membuktikan kapasitas dan kualitasnya di samping mengatasi rasa bersalahnya secara konstruktif;
5) Pelaku didorong untuk bertanggung jawab secara aktif;

6) Pelaku diharapkan untuk menunjukkan empati dan menolong memperbaiki kerugian dan tidak hanya difokuskan pada penghukuman;

7) Pelaku diharapkan untuk meminta maaf dan agar mempunyai rasa penyesalan;

Perkara-perkara di lokasi penelitian yang dilakukan perdamaian atau diselesaikan secara non-litigasi, dapat dilihat dalam tabel berikut ini.

Tabel 6

Jenis dan Jumlah Kasus yang Diselesaikan Secara Kekeluargaan/ Damai atau Non-Litigasi di Bapas Purwokerto yang Disaksikan oleh Pihak Kepolisian Tahun 2002-2008.

\begin{tabular}{|c|l|c|c|}
\hline No. & \multicolumn{1}{|c|}{ Jenis Kejahatan } & Jumlah & Prosentase \\
\hline 1 & Pencurian & 19 & 32,62 \\
\hline 2 & Penganiayaan & 26 & 47,82 \\
\hline 3 & Pembunuhan & - & \\
\hline 4 & Kesusilaan & - & \\
\hline 5 & Pemerasan & - & \\
\hline 6 & Narkoba & - & \\
\hline 7 & Lakalantas & - & \\
\hline 8 & $\begin{array}{l}\text { Membawa Senjata } \\
\text { tajam }\end{array}$ & - & \\
\hline 9 & Pengrusakan barang & 15 & 19,56 \\
\hline 10 & Penipuan & - & \\
\hline 11 & Perjudian & - & \\
\hline & Jumlah & 60 & $100 \%$ \\
\hline
\end{tabular}

Sumber: Dokumen di BAPAS Purwokerto yang diolah, dari tahun 2002 sampai Desember 2008

Berdasarkan tabel ini maka perkaraperkara yang dilakukan perdamaian atau kekeluargaan ataupun non-litigasi sebatas pada perkara-perkara: Pencurian; Penganiayaan; Pengrusakan barang. Sedangkan perkaraperkara lainnya belum terdapat praktik mediasi/ non-litigasi.

Pihak kepolisian, melakukan mediasi dalam perkara-perkara tersebut, karena terdapat beberapa keadaan yang dijadikan alasannya, yaitu:

1) terhadap pelaku masih pelajar, tetap menangkap tetapi dinasihati; 
2) apabila pelaku dan korban saling memaafkan dan diberi ganti rugi, maka perkara sering kali dihentikan;

3) jika anak menyesal dan berjanji tidak akan mengulangi serta orang tua sanggup membimbing, maka polisi perkara dihentikan dan pelaku dikembalikan orang tua.

Keikutsertaan pihak penyidik dalam penyelesaian secara damai dan non-litigasi ini, dalam hal ini berupa:

1) penyidik (polisi) mempertemukan antara pelaku dan korban atau pihak keluarga korban;

2) penyidik memberi kelonggaran (jangka waktu) terhadap pelaku dan korban untuk melakukan musyawarah;

3) penyidik akan mengabulkan atau tidak mengabulkan perdamaian antara pelaku dan korban, akan tetap melihat pertimbangan kepentingan atau kemanfaatan bagi masyarakat dan kondisi nyata antara pelaku dan korban;

4) penyidik akan menghentikan atau tidak meneruskan pelimpahan perkara anak tingkat penuntutan, jika terdapat keadaan seperti : aduan dicabut; tidak cukup bukti; korban telah diberi ganti rugi; karena ada saran dari tokoh masyarakat; ada arahan dari pimpinan agar perkara dihentikan.

Indikator dalam peradilan anak restoratif dapat dilihat dari peran-peran: Pelaku; Korban; masyarakat dan Para profesonal peradilan anak. Masing-masing peran sebagai berikut. ${ }^{14}$

1) Pelaku: pelaku aktif untuk merestore kerugian korban dan masyarakat. la harus menghadapi korban/wakil korban;

2) Korban: akltif terlibat dalam semua tahapan proses dan berperan aktif dalam mediasi dan ikut menentukan sanksi bagi pelaku;

3) Masyarakat: terlibat sebagai mediator mengembangkan pelayanan masyarakat dan menyediakan kesempatan kerja bagi pelaku sebagai wujud kewajiban reparatif, membantu korban dan mendukung pemenuhan kewajiban pelaku;

14 Paulus Hadisuprapto, op.cit.
4) Para profesional: memfasilitasi berlangsungnya mediasi, memberikan jaminan terselenggaranya restoratif, mengembangkan opsi-opsi pelayanan masyarakat secara kreatif/restoratif, melibatkan anggota masyarakat dalam proses, mendidik masyarakat.

Mencermati fakta di lokasi penelitian ini maka peran pihak-pihak dalam praktik mediasi sebagai model peradilan restoratif dalam perkara anak di wilayah hukum Bapas Purwokerto, dapat disimpulkan sebagai berikut.

\section{a. Pelaku}

Peran pelaku dalam model peradilan restoratif bekerja aktif untuk merestore kerugian korban dan masyarakat. Pelaku harus menghadapi korban/wakil korban. Namun demikian peran para pihak dalam praktik peradilan restoratif di Wilayah Hukum Bapas belum aktif, di dalam menghadapi korban, dan pihak pelaku ini diwakili oleh pihak keluargalah yang secara aktif menghadapi korban dan masyarakat.

\section{b. Korban}

Peran korban dalam peradilan restoratif berperan aktif untuk setiap semua tahapan proses, dan korban ikut dalam menentukan sanksi bagi pelakunya. Dalam praktik peradilan restoratif di Wilayah Hukum Bapas Korban hanya sebatas hanya dimintai untuk berdamai dengan pelaku, dan diharapkan tidak dendam kepada pelaku. Korban tidak ikut serta menentukan sanksi bagi pelaku proses mediasi. Hal ini dapat dipahami karena korban adalah pada umumnya masih anak-anak.

\section{c. Masyarakat}

Di dalam peradilan restoratif, masyarakat terlibat sebagai mediator mengembangkan pelayanan masyarakat dan menyediakan kesempatan kerja bagi pelaku sebagai wujud kewajiban reparatif, membantu korban dan dukung pemenuhan kewajiban pelaku. Dalam praktik mediasi di dalam perkara anak di wilayah hukum Bapas Purwokerto, peran masyarakat dalam hal ini diwakili oleh tokoh masyarakat, sebagai mediator dan sebagai wakil masyarakat 
yang menandakan tidak ada dendam lagi di masyarakat. Masyarakat saat ini belum aktif dalam peran pelayanan untuk menyediakan kerja bagi pelaku anak.

\section{d. Penegak hukum Peradilan Pidana Anak}

Peran penagak hukum (para profesional) peradilan pidana anak memfasiltasi berlangsungnya mediasi: memberikan jaminan terselenggaraannya restoratif, kembangkan dan opsi-opsi pelayanan masyarakat secara kreatif/restoratif, melibatkan anggota masyarakat, dalam proses mendidik masyarakat. Di dalam praktik mediasi dalam proses peradilan pidana anak di Wilayah hukum Bapas Purwokerto, Pihak kepolisihan, telah berusaha memfasiltasi berlangsungnya mediasi: memberikan jaminan terselenggaraannya restoratif. Sedang memberikan opsi-opsi pelayanan masyarakat secara kreatif/restoratif, melibatkan anggota masyarakat, belum dilakukan.

E. Simpulan

1. Dasar hukum implementasi peradilan restoratif dalam tahap penyidikan perkara anak dalam sistem peradilan pidana anak di Indonesia, adalah:

a. Pasal 5 ayat (1) huruf a angka 4 KUHAP, di mana penyidik diberi kewenangan dapat melakukan tindakan lain menurut hukum yang bertanggung jawab. Tindakan lain menurut hukum yang bertanggung jawab, yaitu dalam melakukan tindakan ini dengan syarat tidak bertentangan dengan suatu aturan hukum; selaras dengan kewajiban hukum yang mengharuskan dilakukannya tindakan jabatan; tindakan itu harus patut dan masuk akal dan termasuk dalam lingkungan jabatannya; atas pertimbangan yang layak berdasarkan keadaan memaksa, serta menghormati hak asasi manusia.

b. UU Pengadilan Anak Pasal 42 UU No. 3 Tahun 1997 menyatakan, bahwa dalam melakukan penyidikan terhadap Anak Nakal, penyidik wajib meminta pertimbangan atau saran dari Pembimbing
Kemasyarakatan, dan apabila perlu juga dapat minta pertimbangan atau saran dari ahli pendidikan, ahli kesehatan jiwa, ahli agama, atau petugas kemasyarakatan lainnya;

c. Pasal 16 ayat (1) huruf I, ayat (2) dan Pasal 18 UU Nomor 2 Tahun 2002 tentang Kepolisian Negara Republik Indonesia. Ketentuan Pasal 16 ayat (1) huruf I UU Kepolisian Negara Republik Indonesia ini mengatur tentang yang dapat dilakukan oleh kepolisian sehubungan dengan tugas pokok kepolisian dibidang proses pidana, yaitu: "mengadakan tindakan lain menurut hukum yang bertanggung jawab". Tindakan lain ini dengan melihat syarat-syarat tertentu yaitu: tidak bertentangan dengan suatu aturan hukum; selaras dengan kewajiban hukum yang mengharuskan tindakan tersebut dilakukan; harus patut, masuk akal dan termasuk dalam lingkungan jabatannya; pertimbangan yang layak berdasarkan keadaan yang memaksa; dan menghormati hak asasi manusia. Ketentuan Pasal 18 UU No 2 Tahun 2002, mengatur kepolisian negara Republik Indonesia dalam melaksanakan tugas dan wewenangnya dapat bertindak menurut penilaiannya sendiri . dengan memperhatikan peraturan perundangundangan serta kode etik Profesi Kepolisian Negara Republik Indonesia.

d. Surat Telegram Rahasia dari Kabareskrim Polri No. Pol. TR/359/DIT.I/VI/ 2008 tanggal 9 Juni 2008 yang ditujukan kepada Para KAPOLDA UP.DIR RESKRIM, dan Surat Telegram Rahasia dari Kapolda Jateng No.Pol. STR/215/ III/2009, tanggal 30 Maret 2009 yang ditujukan kepada: KAPOLWILTABES SEMARANG, KAPOLWIL JAJARAN POLDA JATENG, KAPOLTABES SURAKARTA, dan KAPOLRES/TA JAJARAN POLDA JATENG, yang menghendaki bahwa kepolisian diharapakan mengimplementasikan restorative justice secara selektif ter- 
hadap perkara anak yang memenuhi syarat-syarat tertentu.

2. Praktik Mediasi Pelaku dan Korban dalam Proses Peradilan Anak di Wilayah Hukum Balai Pemasyarakatan Purwokerto, dilakukan dengan kondisi-kondisi sebagai berikut.

a. Perdamaian antara korban dan pelaku anak ini, dilakukan dalam tahap pemeriksaan penyidikan, sedang dalam tahap penuntutan dan pemeriksaan pengadilan tidak pernah dilakukan mediasi;

b. Perdamaian dalam perkara anak dilakukan sebatas perkara-perkara tertentu, yaitu pencurian, penganiayaan dan pengrusakkan barang, sedangkan perkara-perkara lain tidak ada mediasi. Namun demikian penyidik dapat menerima mediasi terhadap perkara kejahatan kesusilaan setelah memperhatikan kondisi pelaku dan korban, dan tidak meresahkan masyarakat.

c. Perdamaian dilakukan jika kondisi anak masih muda; anak perlu sekolah; orang tuanya sanggup membimbing; tindak pidana termasuk ringan; pihak korban sudah diberi ganti rugi dan memaafkan; kondisi lingkungan masyarakat sekitarnya dinilai layak untuk pembinaan anak tersebut, serta pelakunya belum atau tidak dilakukan penahanan.

d. Perdamaian dalam perkara anak ini terjadi karena peran serta yang menonjol dari keluarga korban, keluarga pelaku dan tokoh masyarakat setempat.

3. Implementasi Mediasi dalam perkara anak di Wilayah Hukum Bapas Purwokerto, belum dapat sepenuhnya dikatakan sebagai Model Peradilan Restoratif. Hal ini didasarkan pada kenyataan bahwa target dari praktik mediasi ini cenderung hanya bertujuan untuk menghindari pemeriksaan lanjutan yaitu penuntutan dan pemeriksaan di pengadilan. Sedangkan tindak lanjut setelah mediasi, yaitu tentang pelayanan dan perindungan bagi korban, tidak terpantau atau sulit dipantau oleh pihak kepolisian, sehingga sejauhmana per- lindungan dan pelayanan korban menjadi tidak jelas.

\section{F. Rekomenadasi}

1. Praktik peradilan restoratif tidak hanya diimplementasikan dalam tahap penyidikan saja, tetapi mestinya dalam tahap penuntutan dan tahap pemeriksaan pengadilan. Oleh karena itu perlu pengaturan baru yang memberi kewenangan bagi penuntut umum dan hakim anak melakukan peradilan restoratif dalam sistem peradilan pidana anak di masa mendatang.

2. Perlu ada format tentang pemantauan tindak lanjut setelah dilakukan mediasi, sehingga korban tetap terlindungi dan terlayani kepentingannya.

3. Praktik mediasi tidak hanya dilakukan terhadap tindak pidana pencurian, penggelapan dan perusakan barang, tetapi diperluas terhadap tindak pidana lainnya yang dilakukan oleh anak.

4. Perlu dilakukan pendidikan bagi penegak hukum tentang mediasi dan implementasinya.

5. Mediasi dalam perkara anak, perlu disosialisasikan pada masyarakat luas, sehubungan dengan adanya Surat Telegram Rahasia tentang pelaksanaan Peradilan Restoratif (Restorative Justice) dari pihak Kepolisian.

6. Pelaksanaan Mediasi perlu ada keterbukaan antara Pelaku, Korban dan Penegak hukum, sehingga para pihak betul-betul mendapatkan manfaat mediasi ini.

\section{DAFTAR PUSTAKA}

Arief, Barda Nawawi. 2007. Masalah Penegakan Hukum dan Kebijakan Hukum Pidana dalam Penanggulangan Kejahatan. Jakarta: Kencana Prenada Media Group;

Hadisuprapto, Paulus. 1997. Juvenile Delinquency Pemahaman dan Penannggulangannya. Bandung: PT. Citra Aditya Bakti;

Herlina, Apong, dkk. 2004. Perlindungan Terhadap Anak Yang Berhadapan dengan 
204 Jurnal Dinamika Hukum

Vol. 9 No. 3 September 2009

Hukum Manual Pelatihan Untuk POLISI. Jakarta: Polri dan Unicef;

Muladi. 2002. Kapita Selekta Sistem Peradilan Pidana, Semarang: Badan Penerbit Universitas Diponegoro;

Riskin, Leonard L \& James E. Westbrook. 1987. Dispute Resolution and Lawyers, St. Paul: West Publishing Co;

Wahyudi, Setya. 2007. Penelitian dan Pengembangan Diversi dalam Sistem Peradilan Anak dalam Sistem Peradilan Pidana Anak di Indonesia. Purwokerto: Hasil Penelitian Fakultas Hukum Unsoed. 